\title{
ОСОБЕННОСТИ ПСИХОЛОГО-ПЕДАГОГИЧЕСКОЙ КОМПЕТЕНТНОСТИ ПРЕПОДАВАТЕЛЯ В ДИНАМИЧНО РАЗВИВАЮЩЕМСЯ СРЕДНЕМ ПРОФЕССИОНАЛЬНОМ ОБРАЗОВАНИИ
}

\author{
Л.В. Мельникова \\ Московский гуманитарный университет
}

\begin{abstract}
Аннотация:Встатьепойдетречьостановленииимодернизачиисреднегопрофессионального образования, а также об особенностях психолого-педагогической компетентности преподавателя в этих условиях.

Ключевые слова: психолого-педагогическая компетентность, среднее профессиональное образование, преподаватель, движение WorldSkills, профессиональные и образовательные стандарты
\end{abstract}

\section{FEATURES OF THE PSYCHOLOGICAL AND PEDAGOGICAL COMPETEHCE OF A TEACHER IN A DYNAMICALLY DEVELOPING SECONDARY VOCATIONAL EDUCATION}

\author{
L.V. Melnikova \\ Moscow University for the Humanities
}

Annotation: the article deals with the formation and modernization of secondary vocational education, as well as the features of the psychological and pedagogical competence of a teacher in these conditions.

Keywords: teacher, secondary vocational education, psychological and pedagogical competence, WorldSkills movement, professional and educational standards.

Современные требования, продиктованные рынком труда, доказывают неоспоримую ценность среднего профессионального образования для развития социально-экономического положения нашей страны. Колледжам отводится важная роль в формировании высококвалифицированного кадрового резерва, от которого зависит подъем в российской промышленности, социальной сфере и бизнесе. Данная позиция была отмечена Президентом Российской Федерации B.В. Путиным на состоявшемся 6 февраля 2020 г. совместном заседании Президиума Госсовета и Совета при Президенте по науке и образованию.

В виду того, что объектом нашего внимания стал не просто преподаватель, а преподаватель системы СПО - системы, имеющей большую значимость не только сегодня, но и в прошлом, считаем необходимым осветить наиболее важные шаги развития данной системы.

Среднее профессиональное образование в России складывалось постепенно, и как отдельная ступень сформировалось лишь в конце XIX в. Известно, что большой вклад в развитие учреждений среднего профессионального образования внес Петр I, созданием профессиональных школ различного типа. 
Образование и воспитание в петровской школе было направлено на приобретение профессиональных навыков. Самой известной считается «Школа математических и навигацких наук» (в последствии, Морская Академия). Профессиональная школа, а ретроспективный анализ позволяет ее так назвать, носила сословный характер, готовила к различным областям государственной службы. Курс состоял из трёх ступеней: начальной (обучение письму, чтению, грамматике и арифметике), цифровой (обучение арифметике, геометрии, тригонометрии), высшей (навигаторские классы). Учащиеся навигаторских классов проходили практику на морских кораблях, судостроительных верфях, на прокладке дорог. Можно заметить, что структура и содержание программы обучения находит отражение в последующих стандартах среднего профессионального образования.

Социокультурная жизнь общества и социально-экономическая политика конца XIX-начала XX вв. требовала всё большего охвата молодого поколения профессиональной подготовкой. Так в России сформировалось около 143 средних специальных учебных заведений, подведомственных различным министерствам, и предлагавшим разнообразную отраслевую направленность. К тому же, в период с 1863 г. по 1917 г. в России в управлении образованием появились четкие, но весьма противоречивые тенденции. А именно, стремление осуществить жесткую централизацию и контроль за образованием одновременно с активной популяризацией неправительственных учебных заведений ввиду развития промышленности и торговли.

После революции в стране среднее профессиональное образование претерпевает глобальные изменения и становится частью системы образования. К 1929 г. в стране возникло 1030 средних специальных учебных заведений. Сроки обучения и планы приема были различными, но главная идея едина -50 \% учебных часов отводились на практическое обучение. В 30-х гг. были разработаны стабильные учебные планы. Данное обстоятельство - еще один масштабный шаг к становлению современного профессионального образования. К 1981 г. система среднего специального образования осуществляла подготовку кадров для всех отраслей народного хозяйства страны более чем по 500 специальностям (Митросенко, 2007). Позднее появился интерес к квалификации специалиста, к широте профиля его подготовки и возникли различные типы образовательных учреждений: профессиональные лицеи, профессиональные колледжи, центры непрерывной подготовки кадров, профессиональные школы и др., появляются термины «дополнительное профессиональное образование» и «другие образовательные услуги».

Как показало исследование, предпосылкой к развитию профессионального образования послужил переход России на рыночные отношения. Масштабные преобразования системы профессионального образования учитывали, как существующую образовательную систему, так и новые концептуальные 
подходы на основе прогнозов, стратегий, в условиях изменяющейся социальнойэкономической политики государства. Система профессионального образования стала предполагать профессиональную социализацию личности, причем в течение всей жизни. То есть, учреждение СПО должно предоставить отдельной личности свободу в выборе образовательных траекторий в соответствии со своими способностями, запросами и возможностями. При этом стоит заметить, что учреждение должно учитывать и потребности заказчиков профессиональных кадров в подготовке мобильных, ориентированных на рыночные отношения специалистов.

Согласимся с исследователями (Никитин, 2019; Блинов, Есенина, Клинк, Сатдыков, Сергеев, Факторович, 2016), полагающими, что пик развития среднего профессионального образования состоялся в 2015 г. Новой масштабной реформе еще только предшествовали поправки в законодательство, отразившие новые ступени образования как в высших учебных заведениях, так и в средне-специальных. Привычные «начальное профессиональное» и «среднее профессиональное» заменили на «программы подготовки квалифицированных рабочих кадров (ППКРС) и программы подготовки специалистов среднего звена (ППССЗ). Увеличение свобод в деятельности профессиональных организаций диктовало выстраивание оригинальных образовательных программ. Многое делалось для повышения престижа среднего профессионального образования. Необходимо заметить, что доля абитуриентов, желающих поступить на программы СПО, систематически увеличивается. По отношению к некоторым отраслям формируется государственный заказ на подготовку кадров. В это самое время модернизация СПО приобрела глобальный характер и отразилась в поручении Президента РФ, поставившего цель: $50 \%$ учреждений СПО к 2020 г. должны осуществить первый выпуск по новым и перспективным профессиям.

Проанализировав современное состояние системы СПО можно отметить ряд ключевых принципов:

- расширяется сотрудничество системы профобразования с работодателями, во главу угла ставится сетевое взаимодействие. Такие договорные отношения предполагают больше вариативности, экономии ресурсов и возможностей, полезных как со стороны учреждения СПО, ведь оно напрямую связано с производством,такисостороныработодателя,поддерживающегообразовательные учреждения в качестве ключевого ресурса собственного развития;

- созданы самые современные межрегиональные центры компетенций (МЦК) для обеспечения подготовки кадров по наиболее востребованным и перспективным профессиям и специальностям среднего профессионального образования, на их базе проходит экспериментальная апробация новых федеральных государственных образовательных стандартов, программ, модулей, методик подготовки кадров по перечню профессий ТОП-50; 
- Россия активно участвует в движении WorldSkills International (WSI, от англ. skills - «умения») «Молодые профессионалы». На некоторых мировых чемпионатах по профессиональному мастерству российские команды мастеров удостаивались медалей за высшее мастерство. В 2019 г. данный чемпионат (мирового уровня) прошел в нашей стране.

Можно с уверенностью сказать, что сегодня по уровню профессионального образования РФ если не опережает, то находится на лидирующих позициях в мире. В любом случае, повысить престиж СПО в нашей стране точно удалось.

О перспективах развития системы СПО наиболее верно, на наш взгляд сказал М.В. Никитин: «Сегодня образовательные организации СПО во многом интегрированы в Национальную квалификационную систему, что позволяет прогнозировать следующий эволюционный переход конкурентоспособности и качества:

первый этап - становление крупного регионального колледжаобразовательного комплекса с развитой сетевой межведомственной инфраструктурой;

второй этап - трансформация такого колледжа в региональный институт сетевого профессионального образования на основе преемственности программ СПО и корпоративного обучения, в том числе, конвертации программприкладного бакалавриата и заочного образования в сетевые формы» (Никитин, 2019).

При толковании степени владения педагогом своей профессией применяют ряд терминов: профессионализм, профессиональная компетентность, педагогическое мастерство, педагогическое искусство, квалификация, причём, зачастую происходит смешение данных понятий. В свете активного обсуждения проблемы компетентностного подхода в образовании особый интерес представляет психолого-педагогическая компетентность, которая является ведущим компонентом профессионального и личностного потенциала.

Изучать психолого-педагогическую компетентность преподавателя имеет смысл, как многофакторное явление, как составляющую профессионализма. Так, требования к преподавателю регламентируются известными правовыми актами: «Законом об образовании», «Единым квалификационным справочником должностей руководителей, специалистов, и служащих», «Федеральным государственным образовательным стандартом среднего профессионального образования», «Стандартом педагога», разработанным Министерством труда.

Если говорить о компетентности личности, то она имеет определенную структуру, компоненты которой связаны со способностью человека решать различные проблемы в повседневной, профессиональной или социальной жизни. В структуре компетентности личности представлены: компетентность в сфере самостоятельной познавательной деятельности; в сфере гражданскообщественной деятельности; в сфере социально-трудовой деятельности; 
компетентность в бытовой сфере; в сфере культурно-досуговой деятельности. А также - навыки самообразования, критического мышления, самостоятельной работы,самоорганизацииисамоконтроля,работывкоманде,уменияпредсказывать результаты, устанавливать причинно-следственные связи, обнаруживать, формулировать и решать проблемы (Рахметова, Сандибаева, Калабаева 2016).

Таким образом, компетентность - это наличие знаний и опыта, необходимых для эффективной деятельности. Само наполнение педагогической компетентности педагогического работника определяется содержанием и функциями профессионально-педагогической деятельности, а также выработанными на этом принципе нормативными требованиями. Психологопедагогическая компетентность в ряде исследований трактуется по аналогии с общей и профессиональной компетентностью и понимается как владение саморегуляцией, т.е. наличие всознаниипреподавателяпсихологических ситуаций (или педагогических задач) и владение способами их решения. По мнению Л.Ф. Красинской психолого-педагогическая компетентность преподавателя представляет собой «интегративное профессионально-личностное образование, заключающееся в способности актуализировать психолого-педагогические компетенции, сформированные на основе соответствующих знаний, умений, ценностей, что обеспечивает эффективное решение профессиональнопедагогических задач» (Красинская, 2011).

В целом, широту понятия «педагогическая компетентность» сложно измерить, оно исследуется уже много лет самими известными учеными и до сих пор имеет потенциал для исследования. Верно то, что психологопедагогическая компетентность - это важный составной элемент общей структуры профессиональной компетентности педагогического работника. При этом психологическую грамотность не редко рассматривают как начальный уровень компетентности. А, в основе любой грамотности или компетентности лежит адекватное использование опыта и сама личность педагога. Поэтому нельзя забывать про личностные качества преподавателя, они должны быть положительными, гармоничными и эффективными. Культура общения и педагогический такт, профессиональная эрудиция, внимательность и отзывчивость, энергичность и самокритичность... Безусловно, это может быть темой отдельного исследования, ведь проблема психолого-педагогической компетентности так многогранна - от способности к самообразованию до отсутствия вредных привычек.

В условиях модернизации среднего профессионального образования требования к психолого-педагогической компетентности преподавателя, безусловно, претерпевают изменения. Произошедшие или еще только планируемые новации среднего профессионального образования диктуют преподавателям системы жесткие требования. 
Так, все чаще говорят о паритете отечественного профобразования мировым стандартам, допускающем в дальнейшем разработку отдельного комплекса мер по совершенствованию профессионального образования. А это может привести к ломке существующего стандарта преподавателя СПО, может потребоваться его «улучшенная формула».

Необходимо отметить, что с 2012 г. регионализация системы СПО привела к размыванию системы методических служб, которыми обусловливалась эффективность педагогического труда и надежность методических систем обучения. Образовательные программы разрабатываются и реализуются с огромным опозданием от профстандартов. Подвергается критике система объективного оценивания качества подготовки выпускников и актуальность используемых преподавателями технологий, часто с недопустимо устаревшим оборудованием.

При этом образовательные стандарты требуют наличия у преподавателя СПО не только педагогического образования, но и профессионального, по конкретному виду деятельности, а также наличия опыта работы в соответствующей отрасли. Данный критерий на практике часто оказывается трудновыполнимым.

Еще одной распространенной проблемой кадрового обеспечения профессионального образования является старение педагогических кадров. В организациях, реализующих программы подготовки специалистов среднего звена, значительно преобладает доля педагогов возрасте от 50 и более лет $(65,7 \%)$, доля работников в возрасте до 30 лет составляет лишь 12,2\%.

В виду тенденции укрупнения образовательных организаций, а также эффективной политики преемственности и неразрывности образовательного процесса, мы выходим за рамки «техникум/колледж», по сути программы СПО могут реализовыватьсяналюбыхплощадках -вузы, организациидополнительного образования, предприятия и даже школы. Можно только предположить, насколько высококомпетентным должен быть преподаватель в столь сложном механизме взаимодействия. При этом высоко оценить можно бесконечные возможности, открывающиеся перед преподавателем системы СПО.

Профессионально компетентным можно назвать преподавателя, который на исключительно высоком уровне исполняет педагогическую деятельность, педагогическую коммуникацию, достигает стабильных положительных достижений в обучении и воспитании студентов. Проанализировав опыт колледжей по работе над развитием психолого-педагогических компетенций преподавателей, можно с уверенностью перечислить формы и методы повышения профессионализма, а именно: создание методических разработок, проведение открытых мероприятий, выступления на заседаниях предметных комиссий, участие в конкурсах профмастерства, публикации, стажировки, проектирование, семинары, решение ситуативных задач, педагогические гостиные, настав- 
ничество, инструктивно-методическое совещания, лекция, творческие отчеты, педагогические мастерские, фестивали, аттестации, творческие лаборатории, мастер-классы, педагогические советы...

Подводя итогвышесказанному, приходится констатировать, что системаСПО диктует необходимость всеобъемлющей организации психолого-педагогической подготовки и повышения квалификации преподавательских кадров средствами дополнительного профессионального образования. Обусловлено данное обстоятельство как минимум тремя причинами:

- во-первых, это строго нормируется законодательством и профессиональными стандартами;

- во-вторых, позволяет преподавателям укрепиться на высших ступенях профессионального мастерства и углубить, зачастую, поверхностные психологопедагогические компетентности;

- в третьих, обеспечивает соответствие квалификации каждого преподавателя современным быстроменяющимся специфическим особенностям системы СПО (инклюзив, международные стандарты, информатизация и другие).

\section{СПИСОК ЛИТЕРАТУРЫ}

Красинская Л.Ф. (2011) Формирование психолого-педагогической компетентности преподавателя технического вуза в системе дополнительного профессионального образования: автореф. д.п.н. (13.00.08). М., С. 41.

Митросенко С.В. (2007) Педагогика среднего профессионального образования: Учебно-методическое пособие. Красноярск: Сиб. фед. ун-т., с. 8.

Никитин М.В. (2019) Современное состояние и оценка среднего профессионального образования (СПО) в Российской Федерации. Лаборатория профессионального образования ИСРО РАО, [Электронный ресурс] URL: http://industryart.ru/sovremennoe-sostoyanie-i-ocenka-srednego-professionalnogoobrazovaniya-spo-v-rossijskoj-federacii-2018-g/ (дата обращения 29.09.2020).

Рахметова Н., Сандибаева Ж., Калабаева Д., (2016) Педагогические условия формирования компетентности будущих педагогов профессионального образования [Электронный ресурс] Международный журнал прикладных и фундаментальных исследований. № 4. - C. 987-990. URL: https://applied-research.ru/ru/article/ view?id=9118 (дата обращения 30.09.2020).

Блинов В.И., Есенина Е.Ю., Клинк О.Ф., Сатдыков А.И., Сергеев И.С., Факторович А.А. (2016), Актуальные вопросы развития среднего профессионального образования: практическое пособие /- М.: Федеральный институт развития образования. 256 с.

Мельникова Лилия Вячеславовна - магистрант 2 курса кафедры педагогики и психологии высшей школы Московского гуманитарного университета. Научный руко- 
водитель: кандидат психологических наук, доцент Е.Е. Иванова. Адрес: 111395, Россия, г. Москва, ул. Юности, д. 5. Тел. +7-919-725-52-08. Эл. адрес: 2291658@mail.ru

Melnikova Lilia Vyacheslavovna - 2nd year master's student of the Department of Pedagogy and Psychology of the Higher School of the Moscow Humanitarian University. Scientific Director: Candidate of Psychological Sciences, Associate Professor E.E. Ivanova. Address: 5 Yunosti str., Moscow, 111395, Russia. Tel. +7-919-725-52-08. E-mail: 2291658@mail.ru

\section{Для цитирования:}

Мельникова Л.В. Особенности психолого-педагогической компетентности преподавателя в динамично развивающемся среднем профессиональном образовании // Научные труды Московского гуманитарного университета. 2020. №6. C. 42-49. DOI: https://www.doi. org/10.17805/trudy.2020.6.8 